\title{
In search of colonial El Niño events and a brief history of meteorology in Ecuador
}

\author{
A. Terneus ${ }^{1}$ and A. Gioda ${ }^{2}$ \\ ${ }^{1}$ ARCHISS Group, Calle Guaranda 131, Quito, Ecuador \\ ${ }^{2}$ UR 32 Great Ice, IRD, B.P. 64501, 34394 Montpellier, France
}

Received: 30 May 2005 - Revised: 14 December 2005 - Accepted: 20 December 2005 - Published: 2 February 2006

\begin{abstract}
This study shows a brief overview of the development of meteorology in Ecuador from historical documentation of climatic events in the Colonial era through to modern data collection. In the colonial era (16th century-1824), historical documents of rogation ceremonies and municipal proceedings, from the Quito area, provide a rich source of climate information, including El Niño events. Our preliminary findings show that very few of the historically documented catastrophes and other marked environmental events in Quito match known El Niño episodes. Independently, the first meteorological data was collected in Ecuador (beginning with La Condamine in 1738), followed by the earliest attempts to build a national meteorological network in the 1860's, linked closely to President Gabriel García Moreno and the Jesuits. The 1925 El Niño phenomenon was the first important meteorological episode recorded with scientific instrumentation in Ecuador, with newspapers providing complementary archives about the extreme impact of this event.
\end{abstract}

\section{Introduction}

With the arrival of the conquistadors in the 1530's, climatic factors, which directly or indirectly influence food security and health, played a fundamental role in establishing settlements. This collision between the New World and the Old World provides the baseline for historical documentation, as prior to European colonization, the indigenous people of the Andes lacked a written language.

This paper presents a short review of the history of meteorology in Ecuador, beginning with historical documents from the Colonial era, providing an invaluable source of climatic information, to the first meteorological data being collected in 1738 heralding subsequent developments.

Correspondence to: A. Gioda

(gioda@msem.univ-montp2.fr)

\section{The Colonial era}

In the historical archives, it is possible to find many descriptions, related to Ecuador, in which the climate always played an important role.

\subsection{General climate accounts}

A description of Quito and its surrounding region in 1757 by the Jesuit missionary, Father Juan Domingo Coletti gives a good example: Two words about the temperature of Quito: it is located on the equatorial line, or putting it this way, in the centre of the torrid zone, which you would think should make it uninhabitable. Instead, Quito enjoys favourable temperatures that make you feel neither too hot or cold and (...) allows you to experience perpetual spring (...)

If these are beautiful qualities to be encouraged, there are others disliked exceedingly: the most annoying climate characteristics being the continuous rains, so bad that a Bishop described the twelve rainy months of the year as occupying thirteen months, let alone the frequent and terrible storms with thunderclaps and lightning flashes (...);

... until one o'clock in the middle of the day, the days are beautiful and blissful and it is not possible to wish for anything more, but afterwards the sky darkens and becomes so miserable that the heart feels oppressed (...) the streets turn into rivers and the plazas into lakes, in such excess that all parts of the city are flooded; it is true that time and time again there are ten or fifteen serene and placid days which allow some relief, and the rains are necessary, but if the sky calms down for more than eight days the local people begin their rogations and processions.

This view of the Quito climate by Father Colleti, perhaps exaggerates the relative importance of the rains, but other aspects coincide with the opinions of the chroniclers, who in general agree on its mildness describing it as: Ever green Quito or Eternal Spring. For the Europeans who came to our territory e.g. Ecuador, they were surprised at the climatological conditions, as what they were used to experiencing 
in one year, they found in the same day, climbing from the coast to the inter-Andean plateau with its valleys and perpetually snow-capped mountains or descending into Amazonia. This aroused the interest of several scientists who visited our regions during the Colonial era, several of whom carried out the first meteorological instrumental observations.

\subsection{Tracking specific climatic events using archives}

In the Colonial era (1534-1824) and the subsequent beginnings of the Republic, calamities, including diseases, earthquakes, droughts, etc., produced major social upheaval. From the municipal proceedings of Quito and the archives of some Colonial churches, it is possible to reconstruct a record of extremely wet or dry years, following the same reliable methods as used in Potosi (Gioda and Prieto, 1999; Gioda and L'Hôte, 2002), in Mendoza (Prieto et al., 1999), and Mexico City (Garza Merodio, 2002) which is summarized by García Herrera et al. (2003). These we have compared with well known El Niño events in Ecuador and Peru tracked by Ortlieb (2002) (Tables 1 and 2).

\section{The development of meteorological studies}

\subsection{First meteorologists in Ecuador (from 1738)}

The first instrumental meteorological data, including basic observations of temperature and atmospheric pressure, were recorded by three French scientists: Charles Marie de La Condamine (a mathematician, physicist, explorer, and geographer, 1701-1774), Louis Godin des Odonnais and Pierre Bouguer, for the Spanish officials, Jorge Juan de Santasilia and Antonio de Ulloa, between 1735 and 1744. These were carried out while measuring the length of an arc of one degree of the meridian at the equator and they used a Réaumur thermometer only invented in 1730 .

The meteorological data are referred to subsequently by Father Federico C. Aguilar, a Jesuit missionary, in the Weather Bulletin of the National Observatory (published 15 April, 1868):

- According to La Condamine and the Jesuit missionary Father Milanesio, the temperature of Quito in 1738, had a range between $14^{\circ}$ and $15^{\circ}$ Réaumur $\left(17.5^{\circ}\right.$ and $\left.18.75^{\circ} \mathrm{C}\right)$.

- Alexander von Humboldt found in 1802 a mean temperature of $14.4^{\circ}$ Réaumur for Quito".

- Francisco José de Caldas (a Colombian astronomer and naturalist, 1771-1816) in 1804 found a mean in Quito of $12^{\circ}$ Réaumur or $15^{\circ} \mathrm{C}$.

- Jean-Baptiste Boussingault (a French agronomist and chemist, 1802-1887), who measured the air temperature at a short distance from the ground, found for Quito in $1831,15.2^{\circ} \mathrm{C}$.
- With a mean temperature of $14.91^{\circ} \mathrm{C}$, we [Aguilar and his staff] have come very close to those measured by Boussingault, which seems to us to be more exact than those of other physicists (Table 3).

It is important to emphasize that in the same publication referred to, it is stated: Humboldt in Mélanges de Géologie et Physique, Généralités, says speaking about Boussingault: I am referring to a very exact work that he published (July, 1833) in the Annals of Chemistry". Humboldt added: At another time, my observations gave me for Quito $14.4^{\circ} \mathrm{C}$.

Finally, to independently confirm these measurements (Table 3), it is worth noting Father Aguilar's comments: The observations carried out with excellent instruments by the colonels Hall and Salaza, between 1825 and 1828, give an average temperature for Quito of $15.4^{\circ} \mathrm{C}$ (Hall) and $15.5^{\circ} \mathrm{C}$ (Salaza).

A few years later, Carlos Aguierre Montúfar, presented at the Permanent Secretariat of the Academy of Natural Sciences in Paris (19 May, 1851), a meteorological report on observations carried out on the snow covered volcano Antisana, at $4550 \mathrm{~m}$ a.s.l. between December 1845 and December 1846. He recorded simultaneously the temperature and atmospheric pressure in Quito and at the volcano (possibly close to Lake Mica), including determining the "Inversion" between $133.5 \mathrm{~m}$ at $06.00 \mathrm{a} . \mathrm{m}$. and at $125.2 \mathrm{~m}$ at midday for every different degree in Celsius between both localities.

From his records for Quito in 1846, Carlos Aguierre Montúfar deduced that it was $14.5^{\circ} \mathrm{C}$, as well as adding rainfall data for December 1845 and from January until August, 1846.

\subsection{The San Luis National College Observatory, Quito (1864-1875)}

During the 19th century, various countries were developing a scientific and systematic approach to meteorological studies and it was at this time that the President of Ecuador, Gabriel Garcia Moreno (Head of State between 1861-1875) became involved with the installation of the first meteorological observatory in the San Luis National College of Quito. Observations by Jesuits began there in June 1864 under the directorship of Father Federico C. Aguilar (1865-1868) who benefited from the excellent relationship between the State and the Church at this time. However, the observatory was closed immediately after President Moreno was killed in 1875.

On 13 April, 1868, Father Federico C. Aguilar published The Historical and Scientific Report in which were outlined the statistics of parameters such as: atmospheric pressure, air temperature, averages and extremes, humidity, and other atmospheric phenomena, calculated with information from an August's psychrometer, including rainfall, cloudiness, storms, hailstones, winds, etc.

We have found data collected by Aguilar from the following periods: June-December, 1864; January-May, 1865; January-December, 1866.

In 1869, President Moreno developed a project with the intention of turning the Central University of Quito into a 
Table 1. Rogations to Our Lady of Guápulo (northeastern district of Quito) to bring about favourable climate conditions. The novena was very important in case of lack of rain: a nine days' public devotion in the Catholic Church to obtain special graces i.e., the return of the rains.

\begin{tabular}{|c|c|}
\hline $\begin{array}{l}\text { November 1611-January } 1612 \\
\text { (not related with El Niño following Or- } \\
\text { tlieb, 2002) }\end{array}$ & $\begin{array}{l}\text { "... Don Sancho Díaz de Zurbano, proposed to the Municipal Council to ask the } \\
\text { Bishop and the faithful to carry out processions and public rogations, with one } \\
\text { of the images of major devotion; as contagious diseases were decimating the } \\
\text { population, combined with a strong drought that was ruining the sowings"... } \\
\text { "They all turned their imploring looks to Our Lady of Guápulo." }\end{array}$ \\
\hline $\begin{array}{l}1621 \\
\text { (not related with El Niño following Or- } \\
\text { tlieb, 2002) }\end{array}$ & $\begin{array}{l}\text { "It was during the course of the year of } 1621 \text { when again the scourge of } \\
\text { the hunger afflicted these regions: a pertinacious and devastating drought } \\
\text { was transforming what were the green fields of Quito and its surroundings to } \\
\text { brownish-grey and ashen" (...) } \\
\text { "The reverberating sun and the absolute lack of rains". } \\
\text { At the bottom of a canvas from the Vestry of the Sanctuary is written: "in the } \\
\text { year of } 1621 \text { there was in the city of Quito a big drought that opened up the } \\
\text { land with many cracks and all the cattle died, and people were on the point of } \\
\text { perishing, without having agreed to take the Virgin in procession and put her } \\
\text { into Santa Barbara...". } \\
\text { From an unpublished work of Abelardo Iturralde, the following information } \\
\text { was obtained: "1621. There was a great and alarming drought that reigned in } \\
\text { Quito (Ecuador) at the end of which the priests and faithful made rogations in } \\
\text { Santa Barbara; the recollection of this occurs also in an oil painting in Guápulo } \\
\text { church." }\end{array}$ \\
\hline $\begin{array}{l}12 \text { April } 1641 \\
\text { (not related with El Niño following Or- } \\
\text { tlieb, 2002) }\end{array}$ & $\begin{array}{l}\text { "The most severe must have been the winter of the year of } 1641 \text { in these re- } \\
\text { gions; there is so much rain, that the seeds begin to rot on sowing." }\end{array}$ \\
\hline $\begin{array}{l}31 \text { January } 1652-5 \text { October } 1652 \\
\text { (not related with El Niño following Or- } \\
\text { tlieb, 2002) }\end{array}$ & $\begin{array}{l}\text { "A frightful drought, similar in everything to that of } 1621 \text { is felt again: the } \\
\text { fields turned hard and are uncultivable to such a point that the cattle are not } \\
\text { finding enough grass to eat in the pastures, that they began to die". }\end{array}$ \\
\hline $\begin{array}{l}1657 \\
\text { (not related with El Niño following Or- } \\
\text { tlieb, 2002) }\end{array}$ & $\begin{array}{l}\text { "The scourge of the "pest" is combined with a severe winter, precisely in the } \\
\text { days in which the summer becomes more pronounced (dry season) for us" Ro- } \\
\text { gations to the Virgin of the Quinche. }\end{array}$ \\
\hline $\begin{array}{l}24 \text { October } 1669 \\
\text { (not related with El Niño following Or- } \\
\text { tlieb, 2002) }\end{array}$ & $\begin{array}{l}\text { "For an agreement written in the municipal proceedings on } 24 \text { October, } 1669 \text {, } \\
\text { so that the image of Our Lady is brought under Guadalupe's dedication, as it is } \\
\text { known that there is such a great drought in this province that cattle are dying } \\
\text { for lack of pasture." }\end{array}$ \\
\hline $\begin{array}{l}\text { January } 1683 \\
\text { (not related with El Niño following Or- } \\
\text { tlieb, 2002) }\end{array}$ & $\begin{array}{l}\text { "The year of } 1682 \text { was coming to an end, and the little summer of Christmas had } \\
\text { turned into a devastating drought"; and for this reason the Virgin of Guápulo } \\
\text { is moved to the city. }\end{array}$ \\
\hline $\begin{array}{l}19 \text { February, } 1687 \\
\text { (related with El Niño following Ortlieb, } \\
\text { 2002) }\end{array}$ & "Strong drought destroys the fields." \\
\hline $\begin{array}{l}\text { September } 1691 \\
\text { (not related with El Niño following Or- } \\
\text { tlieb, 2002) }\end{array}$ & "Disease followed a terrible drought." \\
\hline $\begin{array}{l}1693-1694 \\
\text { (not related with El Niño following Or- } \\
\text { tlieb, 2002) }\end{array}$ & $\begin{array}{l}\text { "As a natural consequence of such a prolonged drought that took place be- } \\
\text { tween } 1693 \text { and } 1694 \text { yet again another outbreak of smallpox..." }\end{array}$ \\
\hline $\begin{array}{l}1698-1699 \\
\text { (not related with El Niño following Or- } \\
\text { tlieb, 2002) }\end{array}$ & $\begin{array}{l}\text { "This scourge was preceded by that of the drought." This is referred to in the } \\
\text { earthquake in Ambato, Latacunga and Riobamba. }\end{array}$ \\
\hline $\begin{array}{l}21 \text { February } 1716 \\
\text { (not related with El Niño following Or- } \\
\text { tlieb, 2002) }\end{array}$ & $\begin{array}{l}\text { "That is brought from Guápulo to the Virgin of the same name". Novena to } \\
\text { achieve "the suspension of the rains to stop crop loss." (Municipal proceed- } \\
\text { ings) }\end{array}$ \\
\hline $\begin{array}{l}1761 \\
\text { (related with El Niño following Ortlieb, } \\
2002 \text { ) }\end{array}$ & $\begin{array}{l}\text { "Quito endured during sowing the devastating consequences of a prolonged } \\
\text { summer." }\end{array}$ \\
\hline $\begin{array}{l}1787 \\
\text { (not related with El Niño following Or- } \\
\text { tlieb, 2002) }\end{array}$ & "The scourge of a persistent drought presented itself." \\
\hline $\begin{array}{l}4 \text { February } 1797 \\
\text { (not related with El Niño following Or- } \\
\text { tlieb, 2002) }\end{array}$ & $\begin{array}{l}\text { "The earthquake of } 4 \text { February, 1797, as that of } 20 \text { June, } 1698 \text { ", was preceded } \\
\text { by a devastating drought."1 }\end{array}$ \\
\hline
\end{tabular}

${ }^{1}$ Source: 'Guápulo y su santuario’ by the Priest Juan de Dios Navas, Library of the Pontifical Catholic University of Ecuador (Quito). 
Table 2. Rogations and requests to our lady of Guadalupe in relation to epidemics in Quito.

\begin{tabular}{|c|c|}
\hline $\begin{array}{l}11 \text { November } 1611 \text { (drought) } \\
\text { (not related with El Niño following Or- } \\
\text { tlieb, 2002) }\end{array}$ & $\begin{array}{l}\text { "One such outbreak of typhoid fever and measles took hold of the city, making } \\
\text { many victims of the inhabitants." "The dawning of the new year of } 1612 \text { was } \\
\text { distingished by small black flags indicating that the city of San Francisco of } \\
\text { Quito was in mourning". }\end{array}$ \\
\hline $\begin{array}{l}25 \text { April } 1641 \text { (wet) } \\
\text { (not related with El Niño following Or- } \\
\text { tlieb, 2002) }\end{array}$ & $\begin{array}{l}\text { "They were carrying out a novena... due to the excessive rains which added to } \\
\text { the spread of typhoid fever and other diseases. } 1\end{array}$ \\
\hline $\begin{array}{l}\text { February-March } 1645 \\
\text { (not related with El Niño following Or- } \\
\text { tlieb, 2002) }\end{array}$ & $\begin{array}{l}\text { "The year of } 1645 \text {, was extremely troubled and calamitous". "To the quakes, } \\
\text { another terrible scourge was added: the diseases known by the names of } \\
\text { measles and croup. Thousands went to their graves, attacked by a fever and } \\
\text { tiny virulent pustules." }\end{array}$ \\
\hline $\begin{array}{l}\text { January-October } 1652 \text { (drought) } \\
\text { until } 1657 \text { (harsh winter) } \\
\text { (not related with El Niño following Or- } \\
\text { tlieb, 2002) }\end{array}$ & $\begin{array}{l}\text { "And one could not avoid the always terrible and destructive epidemic of small- } \\
\text { pox either" imported once again from Cadiz. "As a result: a cruel and persistent } \\
\text { epidemic of smallpox continued throughout the year of 1657". }\end{array}$ \\
\hline $\begin{array}{l}1677 \\
\text { (not related with El Niño following Or- } \\
\text { tlieb, 2002) }\end{array}$ & $\begin{array}{l}\text { "Our Lady of Guadalupe remained in Quito, because of another smallpox epi- } \\
\text { demic". }\end{array}$ \\
\hline $\begin{array}{l}\text { September } 1691 \text { (drought) } \\
\text { (not related with El Niño following Or- } \\
\text { tlieb, 2002) }\end{array}$ & $\begin{array}{l}\text { "The scourge of the Colonial era were the chronic and devastating epidemics } \\
\text { of smallpox." } \\
\text { "In September, 1691, the epidemic presented itself in the Province of Quito". }\end{array}$ \\
\hline $\begin{array}{l}1693-1694 \text { (drought) } \\
\text { (not related with El Niño following Or- } \\
\text { tlieb, 2002) }\end{array}$ & $\begin{array}{l}\text { "As a natural consequence of the drought that lasted so long between 1693- } \\
\text { 1694, once again epidemics of smallpox, measles and malignant fevers oc- } \\
\text { curred, which caused desolation and death in all the villages of the inter-Andean } \\
\text { plateau, from the North up to the centre of Azuay." }\end{array}$ \\
\hline
\end{tabular}

${ }^{1}$ Actas del Cabildo de Quito (1644). ${ }^{2}$ Actas Capitulares $(1645,1646)$.

Table 3. First values of mean temperatures in the shade (in ${ }^{\circ} \mathrm{C}$ ).

\begin{tabular}{lll}
\hline Observer & Mean & Year \\
\hline Ch. M. La Condamine & $17.5-18.75^{\circ} \mathrm{C}$ & 1738 \\
P. Milanesio s. j. & $17.5-18.75^{\circ} \mathrm{C}$ & 1738 \\
A. von Humboldt & $14.4^{\circ} \mathrm{C}$ & 1802 \\
F. J. Caldas & $15.0^{\circ} \mathrm{C}$ & 1804 \\
Hall & $15.4^{\circ} \mathrm{C}$ & 1828 \\
Salaza & $15.3^{\circ} \mathrm{C}$ & 1828 \\
J.-B. Boussingault & $15.2^{\circ} \mathrm{C}$ & 1831 \\
C. Aguierre Montúfar & $14.5^{\circ} \mathrm{C}$ & 1846 \\
F. C. Aguilar s. j. & $14.5^{\circ} \mathrm{C}$ & 1864 \\
F. C. Aguilar s. j. & $14.91^{\circ} \mathrm{C}$ & 1865 \\
F. C. Aguilar s. j. & $14.19^{\circ} \mathrm{C}$ & 1866 \\
Astronomical Observatory & $13.06^{\circ} \mathrm{C}$ & 1879 \\
\hline
\end{tabular}

Technical School. To firmly establish his ambitions, he contracted a group of German Jesuits, who specialized in various sciences. One of them needed to take charge of the chair of mathematics, as well as being an astronomer, hence, stimulating the creation of an observatory. The first teachers who came to Quito were Johann (Juan) Bautista Menten, Teodoro Wolf and Luis Sodiro.

\subsection{The Astronomical Observatory, Quito (1873-)}

On 7 February, 1873 the government bought for the municipality a plot in the "Avenue" with the intention of building an astronomic observatory, creating the first step in jointly developing astronomic, meteorological and geophysical sciences in Ecuador. The main building was constructed under the direction of Father Juan Bautista Menten, the first director (a German Jesuit professor who succeeded Frederico C. Aguilar in 1870 as Head of Meteorology), finished in 1875 and inaugurated in 1877 (Alenten, 1877).

However, Jesuits were not well accepted by the new government after President Moreno's assassination. Menten left the Jesuits in 1876, and continued working at the observatory with interests also in exploration and teaching (Udías, 2003). The astronomer G. Wickmann was contracted by the government in 1887.

A report sent in 1900 by H. Poincaré, to the Academy of Sciences in Paris mentioned: Quito possesses an observatory provided with good instruments. The French Government has put at the disposal of the Ecuadorian Government, for 5 years, one of our most skilful astronomers, Mr. Gonnessiat, from the Observatory of Lyons. 
Table 4. Milagro - Valdez sugar refinery. Lat. $02^{\circ} 08^{\prime} \mathrm{S}$; Long. $74^{\circ} 33^{\prime} \mathrm{W}$; Altitude $13 \mathrm{~m}$ a.s.l. Mean monthly temperatures and rainfall during 11 years (1920-1930).

\begin{tabular}{|c|c|c|c|c|}
\hline \multirow[b]{2}{*}{ Month } & \multicolumn{3}{|c|}{ Temperature in the shade $\left({ }^{\circ} \mathrm{C}\right)$} & \multirow[t]{2}{*}{ Rainfall (mm) } \\
\hline & Max. & Min. & Mean & \\
\hline January & 31.8 & 21.4 & 26.6 & 401.3 \\
\hline February & 31.8 & 21.3 & 26.6 & 486.8 \\
\hline March & 32.2 & 21.8 & 27.0 & 400.4 \\
\hline April & 32.3 & 21.6 & 27.0 & 236.8 \\
\hline May & 31.3 & 21.2 & 26.3 & 58.7 \\
\hline June & 29.7 & 19.7 & 24.7 & 9.8 \\
\hline July & 29.5 & 19.1 & 24.3 & 0.4 \\
\hline August & 30.1 & 19.1 & 24.6 & 0.6 \\
\hline September & 30.8 & 19.5 & 25.2 & 1.4 \\
\hline October & 30.7 & 19.6 & 25.2 & 4.5 \\
\hline November & 32.4 & 19.6 & 26.0 & 1.9 \\
\hline December & 32.6 & 20.7 & 26.7 & 59.5 \\
\hline Year & 31.3 & 20.4 & 25.9 & 1662.1 \\
\hline
\end{tabular}

Subsequently, Ecuadorian scientists, such as the geologist and naturalist Augusto N. Martínez Holguín, and Luis Eduardo Mena, among others have been its directors.

1890-91 marks a major threshold, as from this time meteorological studies were carried out scientifically, during long periods, with well equipped stations having standardized instrumentation and across different zones of the country; this network was to be markedly expanded at the beginning of the 20th century.

\subsection{Other meteorological stations}

The chronological sequence of stations established was as follows:

- ${ }^{1}$ Gualaquiza 1894

- ${ }^{2}$ Guayaquil 1895

- Ambato 1897

- Baños 1915

- Tulcán, Ibarra, Guaranda, Cuenca, Loja and Machala 1929

\footnotetext{
${ }^{1}$ The first meteorological station installed outside of Quito, was in 1894 at Gualaquiza, in the Amazonian region, and it was directed by Salesian priests, some of whom were European, and were aware of the importance of these studies; unfortunately, in July, 1895 a fire destroyed the mission, including the meteorological station.

${ }^{2}$ The meteorological station at Guayaquil was established on 10 October 1895 in the San Vicente National College. From the meteorological bulletins that came to Quito, to the Jesuit Father Luis Sodiro, only the numbers 26 and 27 of January and February, 1898 and those corresponding to April until August, 1899 were found in the Aurelio Espinosa Pólit Library, which indicates that the missing bulletins, beginning with number 1 date back to December 1895 .
}

Table 5. Milagro - Valdez sugar refinery. Annual rainfall during 11 years (1920-1930).

\begin{tabular}{ll}
\hline Year & $\mathrm{mm}$ \\
\hline 1920 (10 months) & 675.8 \\
1921 & 1152.7 \\
1922 & 1820.8 \\
1923 & 1811.0 \\
1924 & 1100.7 \\
$\underline{1925}$ & $\underline{2813.0}$ \\
1926 & 1910.5 \\
1927 & 1189.0 \\
1928 & 1697.0 \\
1929 & 2090.0 \\
1930 (9 months) & 1442.0 \\
\hline
\end{tabular}

Source: Archives of the Astronomical Observatory of Quito; Statistical analyses: A. Terneus.

On the 20 October, 1944, by Presidential Decree, Dr. Jose Maria Velasco Ibarra, organized the Meteorological Service of the Astronomic Observatory of Quito, complying with the resolutions reached at the scientific congresses organized in Rio de Janeiro in 1935 and Montevideo in 1939 (Acosta Solís, 1944).

Subsequently, these services were developed with the Department of Defence. By means of Executive Decree 1446 on 4 August, 1961, the National Institute of Meteorology and Hydrology (INAMHI) was created, a fundamental step for the standardization of meteorological and hydrological investigations. As a result, Ecuador entered into the world network of meteorology, and has successfully remained up to date.

\section{The El Niño Phenomenon of 1925}

During 1925 in Milagro, in the province of Guayas, the meteorological station of the sugar refinery Valdez, recorded $2813 \mathrm{~mm}$ of rain. The annual average, according to records including the years 1920-1930 was $1662 \mathrm{~mm}$ (Tables 4 and 5).

As a result of excessive rains in the coastal region, the railway line was blocked for more than $60 \mathrm{~km}$, due to undercutting caused by rising levels of the rivers Chimbo and Chanchán, near Huigra. The repairs will take between four and six months, with the participation of thousands of workers stated the newspaper El Telégrafo (1925). The situation was chaotic as not only the railway line, bridges and platforms were affected, but also the highway to Yaguachi and the telegraphic system suffered the devastating impact of the rivers.

The railway during this era was the major transport system for connecting the coastal region with the sierra cities. The severe winters, as recorded in 1925, provoked critical shortages of basic products such as sugar, salt, fuels, etc., for the 


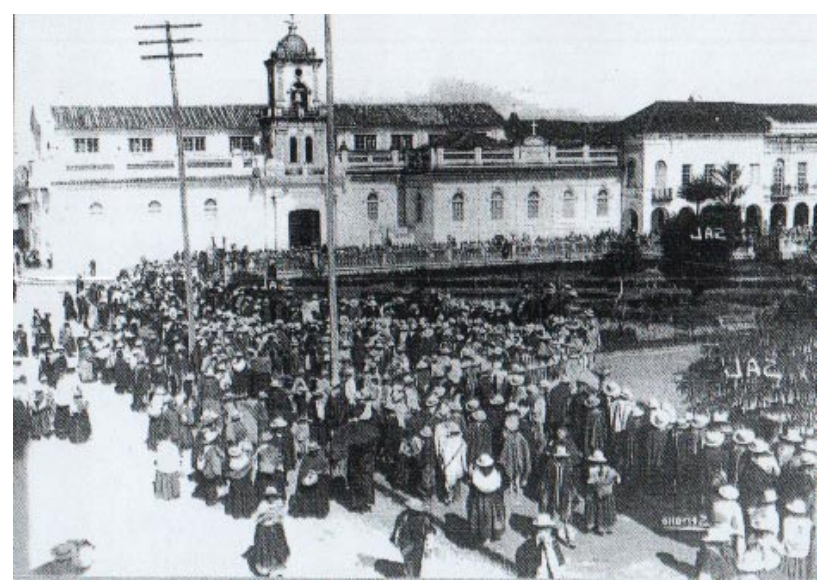

Fig. 1. The demonstration on 28 April, 1925 in Cuenca before the riot. Photo: Manuel Jesús Serrano

sierra populations, simultaneously as the coastal populations were running out of provisions from the inter-Andean region.

On 28 April 1925, driven to despair as the city was not able to acquire any valuable commodities such as salt, we went out into the streets to shout Salt or blood! That a real riot occurred was never recorded in Cuenca. An angry woman was asking at the top of her voice to be given a gun to stop those hoarding it (...). Several speakers, including Dr. Remigio Tamaris Crespo, President of the La Salle Worker Society, Aurelio Vasquez, and President of the Labour Alliance, Francisco Cisneros, as well as several priests asked for calm, since neither the government nor the local authorities could control this critical situation, as nature had placed us in this dramatic and calamitous predicament. In: Octavio Sarmiento, Cuenca and I-Reminiscences, volume 2.

On 25 March, 1925, the newspaper El Telégrafo reported also the flooding devastation in Peru, showing the wide scale impact of this El Niño event. As a result of the suspension of the train service and the continuous rains in the coastal area, two serious problems have occurred: lack of sanitation and difficulties supplying food. Lakes have formed in the towns, constituting a threat to health; and the flooding of fields has caused major crop loss, which will cause a high cost of lives in Lima.

\section{Conclusions}

At this stage in our research using historical documents, from mostly religious archives, it appears that there were more extreme events, especially droughts, during the 17th century than the 18th century. Our preliminary findings show that very few of the historically documented catastrophes and other marked environmental events in Quito in fact match known El Niño episodes. This may be because there is no simple relationship between the occurrence of El Niño episodes on the coast and their manifestation in the Andes following the conclusions of 20th century series studies
(Vuille et al., 2000; Villacis, 2001). Continuous observations in meteorology began from 1891 in Quito after the first attempts by explorers (such as La Condamine, 1738) and the Jesuits (1864-1876). Records documenting the 1925 El Niño phenomenon show on the Ecuadorian coast greater precipitation than the 1982-83 episode. If such an event was to occur today, with the greater population and infrastructural density, the impact would be certainly more catastrophic.

Acknowledgements. The authors are grateful for the financial support from Unesco's International Hydrological Programme (IHP), and its Regional Office in Montevideo, by the incorporation of this work into the framework of the ARCHISS project and also for the facilitation of the information to the National Archives of Ecuador (ANE) and to the National Institute of Meteorology and Hydrology (INAMHI) with a special acknowledgement to Ing. Gonzalo Ontaneda.

A. Chepstow-Lusty (UMR CNRS Paléoenvironnements, University of Montpellier 2, France) helped with the translation.

Edited by: P. Fabian and J. L. Santos

Reviewed by: one anonymous referee

\section{References}

Archival sources in Quito:

National History Archives

Astronomic Observatory

Aurelio Espinosa Pólit Library

Library of the Pontifical Catholic University of Ecuador

Acosta Solís, M.: Breves anotaciones sobre la historia de la climatología del Ecuador, Imprenta Ecuador, Quito, 1944.

Aguilar s. j., F. C.: Boletín meteorológico - Resumen de las observaciones meteorológicas hechas en el Colegio Nacional de Quito, desde le 7 de junio de 1864 hasta el 7 de junio de 1965, Imprenta Nacional, Quito, 1865.

Aguilar s. j., F. C.: Boletín meteorológico del observatorio del Colegio Nacional de Quito, Segundo año 1866, Imprenta Nacional, Quito, 1868.

Alenten, J. B.: Historia y descripción del Observatorio Astronómico de Quito, Imprenta Nacional, Quito, 1877.

El Telégrafo: Las inundaciones en la via férrea, no. 14.280, 23 de marzo, Newspaper, Guayaquil, Ecuador, 1925.

García Herrera, R., García, R. R., Prieto, M. R., Hernández, E., Gimeno, L., and Díaz, H. F.: The Use of Spanish Historical Archives to Reconstruct Climate Variability, Bulletin of the American Meteorological Society, 84, 8, 1025-1035, 2003.

Garza Merodio, G. G.: Frequencias y duración de sequías en la cuenca de México de fines del siglo XVI a mediados del XIX, Investigaciones géográficas, UNAM, México, 48, 106-115, 2002.

Gioda, A. and L'Hôte, Y.: Archives, histoire du climat et pluviométrie: un exemple sud-américain, La Houille Blanche, 4/5, 44-50, 2002.

Gioda, A. and Prieto, M. R.: Histoire des sécheresses andines: Potosi, El Niño et le Petit Age Glaciaire, La Météorologie, 8, 27, 33-42, 1999.

Ortlieb, L.: Manifestations historiques du phénomène El Niño en Amérique du Sud depuis le XVIe siècle, La Houille Blanche, 6/7, 115-120, 2002. 
Prieto, M. R., Herrera, R., and Dussel, P.: Historical Evidences of Streamflow Fluctuations in the Mendoza River, Argentina, and their Relationship with ENSO, The Holocene, 9, 4, 473-481, 1999.

Udías s. j., A.: Searching the Heavens and the Earth: The History of Jesuit Observatories, ASSL 286, Kluwer, Dordrecht/Boston/London, 2003.
Villacis, M.: Influencia de El Niño-Oscilación del Sur sobre la precipitación en los Andes centrales del Ecuador, Tesis de grado, Esc. Pol. Nac., Quito, Ecuador, 2001.

Vuille, M., Bradley, R. S., and Keimig, F.: Climatic variability in the Andes of Ecuador and its relation to tropical Pacific and Atlantic sea surface temperature anomalies, J. Climate, 13, 2520-2535, 2000. 